\title{
Jurist-Diction
}

Volume 3 No. 6, November 2020

\section{Kewajiban Pengusaha Menyediakan Ruang dan Waktu Laktasi Bagi Pekerja Wanita Menyusui}

\author{
Timothy Ronald Marpaung \\ marpaungreunald@gmail.com \\ Universitas Airlangga
}

\begin{abstract}
How to cite:
Timothy Ronald Marpaung,

'Kewajiban Pengusaha

Menyediakan Ruang Dan

Waktu Laktasi Bagi Pekerja

Wanita Menyusui' (2020) Vol.

3 No. 6 , November Jurist-

Diction.

Histori artikel:

Submit 14 Agustus 2020;

Diterima 12 September 2020;

Diterbitkan 1 November 2020.

DOI:

10.20473/jd.v3i6.22975

\section{(2) (i) (9)}

\begin{abstract}
Abstrak
Hak buruh perempuan untuk menyusui pada waktu kerja adalah bagian dari hak reproduksi wanita. Perlindungan hak buruh khususnya buruh perempuan telah banyak diatur dalam berbagai peraturan perundangundangan di Indonesia, namun pada praktiknya pemenuhan hak terhadap buruh perempuan masih belum maksimal. Perjanjian Kerja Bersama dalam hal ini menjadi payung hukum yang kuat bagi pemenuhan hak tersebut. Mengenai hak untuk menyusui pada waktu kerja, perselisihan yang dapat terjadi adalah perselisihan hak dan perselisihan kepentingan. Perselisihan hak terjadi apabila hak buruh untuk menyusui tersebut tidak dicantumkan dalam perjanjian Kerja Bersama, sebaliknya perselisihan kepentingan terjadi apabila hak buruh untuk menyusui tersebut sudah dicantumkan dalam Perjanjian Kerja Bersama tetapi tidak dipenuhi. Maka dari itu, diperlukan kesadaran dari buruh dan juga pengusaha untuk pemenuhan hak menyusui sesuai dengan yang telah diatur dengan peraturan perundang-undangan yang berlaku.

Kata Kunci: Hak Reproduksi Wanita; Hak Menyusui; Hak dan Kewajiban Buruh dan Majikan; Perjanjian Kerja Bersama.
\end{abstract}

\section{Pendahuluan}

Pada era modern ini, pekerja sudah tidak lagi didominasi oleh kaum laki-laki. Selain itu, wanita karir dan perempuan yang menjadi tulang punggung keluarga telah menjadi hal yang lumrah di masyarakat. Bukan tanpa sebab, karena terbukti bahwa terdapat aspek-aspek dalam dunia kerja yang dengan mudah dapat dikuasai oleh kaum perempuan, sebagai contoh adalah petugas teller bank, dimana pada profesi tersebut kaum perempuan dinilai lebih luwes dan teliti dalam melayani para nasabah.

Menurut data Badan Pusat Statistik, tingkat partisipasi angkatan kerja pada tenaga kerja perempuan dalam kurun waktu satu tahun meningkat sebanyak $0,06 \%$. 
Sedangkan pada tahun sebelumnya terdapat kenaikan $0,4 \% .{ }^{1}$ Meskipun tenaga kerja masih didominasi oleh kaum laki-laki, setidaknya data tersebut menunjukan bahwa terdapat kenaikan persentase tingkat partisipasi angkatan kerja perempuan yang bersifat konstan, yaitu selalu meningkat setiap tahunnya. Selain itu, menurut Badan Pusat Statistik diperkirakan bahwa pada tahun 2032 jumlah penduduk perempuan akan lebih banyak daripada penduduk laki-laki. Hal ini juga dapat menjadi gambaran bahwa tingkat partisipasi angkatan kerja khususnya perempuan akan selalu bertambah.

Disebutkan bahwa laki-laki dan perempuan dalam dunia kerja adalah setara, namun perlu diperhatikan bahwa terdapat keistimewaan yang bersifat biologis yang melekat pada diri setiap perempuan yaitu menstruasi atau haid, hamil, melahirkan, dan menyusui anak-anaknya. Dalam hal ini perempuan memiliki tanggung jawab sebagai seorang ibu bagi anak-anaknya. Dan sebaliknya, keistimewaan yang hanya ada pada perempuan tersebut juga menjadi suatu hak baginya. Salah satu bagian dari hak asasi manusia adalah hak-hak yang melekat pada diri perempuan.

Air Susu Ibu (selanjutnya disebut ASI) adalah makanan utama bayi yang baru lahir, yang mana memuat semua energi dan nutrisi yang dibutuhkan oleh bayi selama 6 bulan dan diteruskan hingga umurnya mencapai 2 tahun. 6 bulan pertama dilakukan secara eksklusif, yakni bayi hanya mengkonsumsi ASI dari ibunya tanpa mengkonsumsi makanan ataupun minuman lain. ${ }^{2}$ Diketahui bahwa anak-anak yang mendapatkan ASI untuk periode waktu yang lebih lama memiliki tingkat mortalitas yang lebih rendah dan kecerdasan lebih tinggi daripada anak-anak yang mendapatkan ASI dengan periode waktu yang lebih singkat, hal ini akan bertahan pada kehidupan anak-anak tersebut secara persisten. ${ }^{3}$ Selain itu, bukti-bukti menunjukkan bahwa pemberian ASI dapat melindungi anak dari obesitas dan diabetes pada tahap-tahap

\footnotetext{
1 Badan Pusat Statistik: Keadaan Angkatan Kerja di Indonesia Februari 2019. <https:// www.bps.go.id/publication/2019/05/31/a96ce41f72e59d5dfb1cad9f/keadaan-angkatan-kerja-di-indonesia-februari-2019.html>, diakses pada tanggal 29 Juli 2020.

2 WHO: Infant and Young Child Feeding, Model Chapter for Textbooks for Medical Students and Allied Health Professionals, (World Health Organization 2009).[4-5].

3 Cesar G Victora dkk 'Breastfeeding in the 21st Century: Epidemiology, Mechanisms, and Lifelong Effect', (2016) 387 The Lancet Journal.[2].
} 
dalam kehidupannya. ${ }^{4}$ Sedangkan untuk ibu, menyusui dapat mencegah kanker payudara, meningkatkan jarak kelahiran, dan dapat mengurangi resiko diabetes dan kanker ovarium. ${ }^{5}$

Dengan kata lain, ibu yang tidak menyusui anaknya jelas merugikan dirinya sendiri. Kerugian ini terbagi menjadi kerugian ekonomis dan biologis. Kerugian ekonomis mencakup biaya yang perlu dikeluarkan untuk membeli susu formula sebagai pengganti ASI untuk bayinya. Sedangkan kerugian biologis dapat disimpulkan pada paragraf sebelumnya, yang mana bukan hanya kerugian dirasakan pada diri ibu namun juga dirasakan oleh bayi. Sedemikian pentingnya laktasi atau pemberian ASI kepada bayi, maka tidak salah jika menyusui disebut sebagai salah satu langkah pertama bagi seorang manusia untuk mendapatkan kehidupan yang sehat dan sejahtera.

Dewasa ini dalam dunia kerja khususnya, pengusaha seringkali tidak memenuhi hak pekerja bahkan melalaikannya. Dalam bahasan ini hak pekerja yang seringkali tidak dipenuhi adalah hak pekerja perempuan untuk menyusui setelah mereka melahirkan. Banyak pengusaha yang menganggap hak-hak pekerja perempuan tersebut tidak penting dan menghabiskan biaya bahkan merepotkan. Tetapi pada kenyataannya terdapat bentrok kepentingan antara pekerja dan pengusaha. Pekerja memiliki kepentingan untuk terpenuhinya hak-hak mereka sebagai pekerja. Berlawanan dengan pekerja, pengusaha berkepentingan untuk meraup laba sebesar-besarnya. Sehingga seringkali hak-hak pekerja terkesan menjadi suatu hambatan bagi pengusaha yang ingin meraup laba. ${ }^{6}$ Posisi pekerja dalam dunia kerja adalah pihak yang lemah dari pengusaha, maka dari itu pekerja perlu mendapatkan perlindungan atas hak-haknya. ${ }^{7}$

\footnotetext{
4 ibid.

5 ibid.

6 Catarina Cori Pradnya Paramita, Andi Wijayanto 'Pengaruh Keselamatan dan Kesehatan Kerja terhadap Prestasi Kerja Karyawan pada PT. PLN (PERSERO) APJ Semarang, (2012) 1 Jurnal Administrasi Bisnis,[2].

7 Ni Wayan Mega Jayantri: Perlindungan Hukum Terhadap Pekerja Perempuan Pada Malam Hari di Minimarket Alfamart Mataram (Studi Berdasarkan Undang-Undang Nomor 13 Tahun 2003 tentang Ketenagakerjaan, (2013) Jurnal Ilmiah Fakultas Hukum Universitas Mataram 2013.[4].
} 
Pemenuhan hak perempuan ini juga dilindungi dalam Pasal 27 ayat (2) UUD 1945 yang mengatur bahwa "tiap-tiap warga negara berhak atas pekerjaan dan penghidupan yang layak bagi kemanusiaan", selain itu dalam Pasal 28D ayat (2) yang menyatakan bahwa "setiap orang berhak untuk bekerja serta mendapat imbalan dan perlakuan yang adil dan layak dalam hubungan kerja”. Maka sebagai pelaksana dari pasal-pasal di atas, Undang-Undang Nomor 13 Tahun 2003 tentang Ketenagakerjaan (selanjutnya disebut UU Ketenagakerjaan) dan Undang-Undang Nomor 36 Tahun 2009 tentang Kesehatan (selanjutnya disebut UU Kesehatan) dicantumkan pasal-pasal yang melindungi hak-hak pekerja perempuan, khususnya hak menyusui dan hak mendapatkan sarana yang layak untuk dipenuhinya hak menyusui tersebut. Pasal-pasal tersebut diantaranya adalah Pasal 83 UU Ketenagakerjaan yang mengatur hak menyusui dan Pasal 153 UU Ketenagakerjaan yang mengatur terkait pemutusan hubungan kerja karena hak tersebut. Sedangkan UU Kesehatan mengatur dalam Pasal 128 mengenai kewajiban pengusaha dan Pasal 200 jo. 201 mengenai sanksinya.

Sedangkan dapat diketahui bahwa pemenuhan hak anak juga dilindungi dalam Undang-Undang Nomor 35 Tahun 2014 tentang Perubahan Atas UndangUndang Nomor 23 Tahun 2002 tentang Perlindungan Anak (selanjutnya disebut UU Perlindungan Anak) yang mana dalam Pasal 1 angka 2 perlindungan anak adalah segala kegiatan untuk menjamin dan melindungi anak dan hak-haknya agar dapat hidup, tumbuh, berkembang, dan berpartisipasi secara optimal sesuai dengan harkat dan martabat kemanusiaan, serta mendapat perlindungan dari kekerasan dan diskriminasi. Bahkan dalam Kitab Undang-Undang Hukum Perdata tepatnya dirumuskan dalam buku kesatu mengenai orang yakni dalam Pasal 2 yang menjelaskan bahwa anak yang ada dalam kandungan dianggap telah lahir, hal ini berarti anak tersebut sudah mendapatkan hak perdata bahkan sebelum dia terlahir. Selain itu, dalam Pasal 104 juga hak anak untuk dipelihara orang tuanya dijamin secara tersirat dengan menyebutkan bahwa dengan adanya perkawinan maka suami istri mengikatkan dirinya untuk memelihara dan mendidik anak mereka. 
Salah satu bentuk pemeliharaan orang tua kepada anak adalah pemberian ASI sesuai anjuran yang telah dijelaskan di atas. Maka dari itu hak anak adalah sesuatu yang harus dilindungi sesuai dengan proporsinya. Terlebih lagi dalam Pasal 45 UU Perlindungan Anak juga diatur bahwa orang tua dan keluarga mempunyai tanggung jawab untuk menjaga kesehatan anak serta merawat anak sejak dalam kandungan. Maka terlepas dari pekerjaan orang tuanya, anak tetap wajib dipenuhi haknya sebagai salah satu contoh dengan mendapatkan ASI eksklusif dari ibunya setidaknya hingga berumur 6 bulan sesuai dengan anjuran World Health Organization (WHO).

\section{Hak Menyusui Pada Waktu Kerja}

Dalam bahasan ini, UU Hak Asasi Manusia menjadi landasan hukum yang penting terhadap pelaksanaan dan pemenuhan hak asasi manusia. Khususnya mengenai hak wanita, UU Hak Asasi Manusia memberikan bagian khusus bagi hak wanita didalamnya yaitu pada bagian kesembilan. Beberapa contoh pasal yang memuat hak wanita antara lain:

Pasal 38 ayat (3):

"Setiap orang, baik pria maupun wanita yang melakukan pekerjaan yang sama, sebanding, setara atau serupa, berhak atas upah serta syarat-syarat perjanjian kerja yang sama".

Pasal 38 ayat (4):

"Setiap orang, baik pria maupun wanita dalam melakukan pekerjaan yang sepadan dengan martabat kemanusiaannya berhak atas upah yang adil sesuai dengan prestasinya dan dapat menjamin kelangsungan kehidupan keluarganya".

Ketentuan di atas ditambahkan lebih lanjut dalam Pasal 48, Pasal 49 ayat (1), Pasal 49 ayat (2), Pasal 49 ayat (3), dan pasal 51 ayat (1) sebagai berikut:

Pasal 48:

"Wanita berhak untuk memperoleh pendidikan dan pengajaran di semua jenis, jenjang dan jalur pendidikan sesuai persyaratan yang ditentukan".

Pasal 49 ayat (1):

"Wanita berhak untuk memilih, dipilih, diangkat dalam pekerjaan, jabatan, dan profesi sesuai dengan persyaratan dan peraturan perundang-undangan". 
Pasal 49 ayat (2):

"Wanita berhak untuk mendapatkan perlindungan khusus dalam pelaksanaan pekerjaan atau profesinya terhadap hal-hal yang dapat mengancam keselamatan dana tau kesehatannya berkenaan dengan fungsi reproduksi wanita”.

Pasal 49 ayat (3):

"Hak khusus yang melekat pada diri wanita dikarenakan fungsi reproduksinya, dijamin dan dilindungi oleh hukum".

Pasal 51 ayat (1):

"Seorang isteri selama dalam ikatan perkawinan mempunyai hak dan tanggung jawab yang sama dengan suaminya atas semua hal yang berkenaan dengan kehidupan perkawinannya, hubungan dengan anak-anaknya, dan hak pemilikan serta pengelolaan harta bersama”.

Namun ketentuan-ketentuan dalam UU Hak Asasi Manusia saja dianggap kurang dalam menjamin hak wanita, khususnya dalam dunia kerja. Hal ini karena wanita memiliki perbedaan dengan pria yang bersifat alamiah yang berkaitan dengan fungsi reproduksi. Fungsi reproduksi tersebut menimbulkan adanya hakhak khusus yang berkaitan dengannya yang disebut dengan hak reproduksi. Hak reproduksi wanita merupakan perkembangan konsep hak asasi manusia itu sendiri yaitu mengenai hak-hak untuk mendapatkan pelayanan kesehatan reproduksi dan seksual. Dapat disimpulkan bahwa hak reproduksi juga mengadopsi sifat-sifat hak asasi manusia, salah satunya adalah sifat universal yang menyeluruh dan tidak dapat diabaikan. Hak reproduksi merupakan hak inti manusia yang termasuk dalam hak untuk hidup sehat, bebas dari diskriminasi, hak untuk tidak disakiti atau dianiaya, hak untuk menentukan jumlah anak dan jarak melahirkan, dan hak untuk bebas dari kekerasan seksual. $^{8}$

Maka untuk memenuhi hak tersebut, khususnya yang terkait dalam dunia kerja, diperlukan adanya landasan hukum yang lain yang dapat menjamin hak wanita tersebut. Tahun 2003, pada akhirnya pemerintah mengesahkan peraturan yang mengatur mengenai tenaga kerja dengan Undang-Undang Nomor 13 Tahun 2003

\footnotetext{
${ }^{8}$ Elza Qorina Pangestika ' Pengaturan Hak Menyusui Anak Pada Waktu Kerja Dalam Hukum Ketenagakerjaan', (2018) 24 Wacana Hukum.[2].
} 
tentang Ketenagakerjaan. Dalam UU Ketenagakerjaan, dicantumkan perlindungan hak-hak bagi pekerja yaitu tentang perlindungan waktu kerja dan lembur yang terdapat dalam Pasal 77 hingga Pasal 78, perlindungan waktu istirahat dan cuti yang terdapat dalam Pasal 79, perlindungan pengupahan yang terdapat dalam Pasal 89 sampai dengan Pasal 90, perlindungan jaminan ketenagakerjaan dalam Pasal 99. Selain itu juga terdapat beberapa pasal yang bertujuan khusus untuk menjamin hak wanita di dunia kerja. Diantaranya adalah terkait hak cuti haid yang terdapat dalam Pasal 81 ayat (1), hak cuti melahirkan dan cuti keguguran yang terdapat dalam Pasal 82 ayat (1) dan ayat (2), hak menyusui anak pada waktu kerja yang terdapat dalam Pasal 83, serta larangan pemutusan hubungan kerja yang terdapat dalam Pasal 153 ayat (1).

Adanya UU Ketenagakerjaan ini digunakan sebagai payung dan landasan hukum yang disahkan pemerintah yang memuat hak-hak khusus wanita setidaknya menjadi bukti kesadaran dan kepedulian pemerintah terkait adanya perbedaan alamiah antara pekerja pria dan pekerja wanita. Tetapi hal tersebut masih belum dapat menjamin bahwa pelaksanaan hak-hak tersebut terpenuhi sebagaimana mestinya. Terdapat faktor-faktor yang sangat mempengaruhi yaitu faktor politik, ekonomi, sosial, dan budaya. Namun setidaknya kedudukan hak pekerja untuk menyusui dapat disandarkan pada Pasal 83 UU Ketenagakerjaan.

\section{Perjanjian Kerja Bersama}

Hubungan kerja adalah hubungan antara buruh dan majikan, dimana buruh menyatakan kesanggupannya untuk bekerja kepada majikan dengan menerima upah, dan majikan menyatakan kesanggupannya untuk mempekerjakan buruh dengan membayar upah. ${ }^{9}$ Dengan adanya hubungan kerja, maka konsekuensi logisnya adalah terdapat perjanjian kerja. Yang dimaksud perjanjian kerja adalah perjanjian yang disepakati oleh buruh dan majikan sesuai definisi hubungan kerja di atas. Sedangkan bekerja pada pihak lain harus dikemukakan dengan sifat bekerja

\footnotetext{
9 Iman Soepomo: Pengantar Hukum Perburuhan (Djambatan 1990).[53].
} 
di bawah pimpinan pihak lainnya. Hal ini bertujuan untuk membedakan hubungan kerja dengan hubungan seperti antara pasien dan dokter, dalam artian bahwa dokter bekerja untuk pasien namun tidak di bawah pimpinan pasien. Maka, dokter tidak dapat diartikan sebagai buruh dan pasien tidak dapat diartikan sebagai majikan. ${ }^{10}$

Perjanjian kerja berlainan dengan perjanjian perburuhan atau perjanjian kerja bersama. Perjanjian kerja tidak menimbulkan hak atas dan kewajiban untuk melakukan pekerjaan, tetapi memuat syarat-syarat tentang perburuhan. ${ }^{11}$ Selain itu, perjanjian perburuhan diadakan antara serikat pekerja atau buruh dengan majikan atau perusahaan. Sedangkan perjanjian perburuhan itu sendiri adalah perjanjian yang diadakan oleh satu atau beberapa serikat pekerja yang terdaftar pada departemen tenaga kerja dengan seorang atau beberapa majikan atau perusahaan, satu atau beberapa perkumpulan majikan atau perusahaan yang berbadan hukum yang pada umumnya atau semata-mata memuat syarat-syarat perburuhan yang harus diperhatikan dalam perjanjian kerja. ${ }^{12}$ Jadi, dapat dikatakan bahwa perjanjian perburuhan atau perjanjian kerja bersama berisikan hak dan kewajiban yang mendekati keinginan kedua belah pihak, yaitu pekerja dan majikan. ${ }^{13}$

Untuk syarat sahnya perjanjian perburuhan terdapat dua jenis syarat yang harus dipenuhi yaitu syarat materiil dan syarat formal. Syarat-syarat materiil adalah: ${ }^{14}$

1. Dilarang memuat aturan yang mewajibkan seorang majikan agar hanya menolak atau menerima pekerja dari suatu golongan, baik berkenaan dengan agama, golongan warga negara atau bangsa maupun karena keyakinan politik atau anggota serikat suatu perkumpulan.

2. Dilarang memuat aturan yang mewajibkan seorang pekerja agar hanya bekerja atau tidak boleh bekerja pada majikan dari suatu golongan, baik berkenaan dengan agama, golongan warga negara atau bangsa, maupun karena keyakinan

\footnotetext{
${ }^{10}$ Lanny Ramli: Hukum Ketenagakerjaan, (Airlangga University Press 2008).[23].

11 ibid.

${ }^{12}$ F.X. Djamila Dji dan Wiwoho Soedjono: Perjanjian Perburuhan dan Hubungan Perburuhan Pancasila, (Bina Aksara 1990). [11].

13 ibid. [28].

14 ibid.
} 
politik atau anggota dan suatu perkumpulan.

3. Dilarang memuat aturan yang bertentangan dengan undang-undang tentang Ketertiban Umum atau dengan Tata Susila.

Sedangkan syarat-syarat formal antara lain:

1. Harus diadakan dengan secara tertulis dan ditandatangani oleh kedua belah pihak atau dengan surat resmi, yaitu dihadapan Notaris.

2. Surat perjanjian harus memuat:

a. Nama, tempat kedudukan serta alamat serikat pekerja;

b. Nama, tempat kedudukan serta alamat pengusaha atau perkumpulan majikan yang berbadan hukum;

c. Nomor serta tanggal pendaftaran serikat pekerja pada Departemen Tenaga Kerja;

d. Tanggal penandatanganan.

3. Perjanjian perburuhan harus dibuat sekurang-kurangnya rangkap tiga, selembar harus dikirimkan kepada Departemen Tenaga kerja untuk dimasukkan dalam daftar yang disediakan untuk itu.

4. Perjanjian perburuhan hanya dapat diadakan untuk paling lama dua tahun, dan kemudian dapat diperpanjang dengan paling lama satu tahun lagi.

Secara normatif, isi perjanjian perburuhan atau perjanjian kerja bersama diatur Pasal 124 ayat (1) UU Ketenagakerjaan yaitu sekurang-kurangnya mengenai:

a. Hak dan kewajiban pengusaha;

b. Hak dan kewajiban serikat pekerja serta pekerja;

c. Jangka waktu dan tanggal mulai berlakunya perjanjian kerja Bersama;

d. Tanda tangan para pihak pembuat perjanjian kerja Bersama.

Namun, tidak dapat dipungkiri bahwa perjanjian perburuhan atau perjanjian kerja bersama tidak dapat memuat semua hak dan kewajiban pekerja dan majikan, utamanya hak dan kewajiban pekerja dan majikan yang dipandang mutlak oleh negara. Maka dari itu, di samping perjanjian perburuhan, perjanjian kerja dan peraturan majikan, negara mengeluarkan berbagai peraturan dengan tujuan menciptakan suatu kedudukan yang layak bagi kemanusiaan, baik dalam aspek yuridis maupun sosiologis. ${ }^{15}$

Meskipun jika perjanjian kerja bersama yang tidak mencantumkan hak menyusui tidak batal demi hukum, namun perlu diingat juga bahwa perjanjian

15 ibid.[29]. 
kerja bersama merupakan hasil perumusan oleh pihak pekerja atau buruh dan pihak majikan atau perusahaan, maka jika hak buruh perempuan untuk menyusui tersebut dicantumkan dalam perjanjian kerja bersama, akan menjadi payung hukum yang kuat bagi terpenuhinya kepentingan hak-hak buruh, khususnya hak buruh perempuan terkait menyusui.

\section{Ketentuan Sanksi Bagi Pengusaha Yang Tidak Menyediakan Fasilitas Menyusui Bagi Pekerja Perempuan Menyusui}

Dari beberapa peraturan perundang-undangan yang mengatur mengenai ketentuan hak pekerja perempuan menyusui, hanya Pasal 200 UU Kesehatan yang mencantumkan ketentuan sanksi yang menyatakan bahwa "setiap orang yang dengan sengaja menghalangi program pemberian ASI eksklusif sebagaimana dimaksud dalam Pasal 128 ayat (2) dipidana penjara paling lama satu 1 tahun dan denda paling banyak Rp. 100.000.000,00 (seratus juta rupiah)". Telah dijabarkan secara jelas bahwa ketentuan sanksi di atas merupakan sanksi pidana yang mana merupakan pidana pokok berupa pidana penjara dan pidana denda.

Sedangkan Pasal 201 ayat (1) memberikan ketentuan lebih lanjut, yaitu bahwa "dalam hal tindak pidana sebagaimana dimaksud dalam Pasal 190 ayat (1), Pasal 191, Pasal 192, Pasal 196, Pasal 197, Pasal 198, Pasal 199, dan Pasal 200 dilakukan oleh korporasi, selain pidana penjara dan denda terhadap pengurusnya, pidana yang dapat dijatuhkan terhadap korporasi berupa pidana denda dengan pemberatan 3 kali dari pidana denda sebagaimana dimaksud dalam Pasal 190 ayat (1), Pasal 191, Pasal 192, Pasal 196 , Pasal 197, Pasal 198, Pasal 199, dan Pasal 200". Pasal ini memberikan keterangan lanjutan bahwa jika dalam hal yang melanggar Pasal 128 ayat (2) berbentuk korporasi, maka yang pidana adalah pengurus korporasi tersebut, selain itu terdapat pemberatan pidana denda sebanyak 3 kali bagi korporasi tersebut. Terlebih lagi dalam Pasal 200 ayat (2) disebutkan bahwa korporasi dapat dijatuhi pidana tambahan berupa pencabutan izin usaha dan/atau pencabutan status badan hukum. 


\section{Perselisihan Hubungan Industrial}

Dalam suatu hubungan kerja, perselisihan dapat dibagi menjadi dua bentuk. ${ }^{16}$ yaitu perselisihan hak atau rechtgeschillen dan perselisihan kepentingan atau belang geschillen. Jika perselisihan yang dimaksud masih terkait dengan hubungan kerja, dalam perselisihan hak atau rechtgeschillen objek yang dipermasalahkan ketentuannya sudah diatur pada perjanjian kerja, perjanjian kerja bersama, peraturan perusahaan, atau dalam suatu peraturan perundang-undangan. Sedangkan perselisihan kepentingan atau belangengeschillen disebabkan oleh adanya ketidaksepahaman mengenai perubahan syarat-syarat kerja dan atau keadaan perburuhan, biasanya meliputi tuntutan untuk perbaikan atau perubahan syarat-syarat kerja. Menurut Lanny Ramli, perselisihan kepentingan juga dapat berarti mengenai usaha mengadakan perubahan dalam syarat-syarat perburuhan yang oleh organisasi dituntut pada pihak pengusaha. ${ }^{17}$ Perselisihan hak atau rechtgeschillen dapat terjadi karena perbedaan pelaksanaan suatu ketentuan maupun diskriminasi terhadap suatu ketentuan atau perbedaan cara penafsiran terhadap ketentuan. Sedangkan UndangUndang Nomor 2 Tahun 20014 membagi perselisihan hubungan industrial menjadi 4 jenis perselisihan hubungan industrial antara lain meliputi:

a. perselisihan hak;

b. perselisihan kepentingan;

c. perselisihan pemutusan hubungan kerja; dan

d. perselisihan antar serikat pekerja atau buruh dalam satu perusahaan.

Selain itu Pasal 1 angka 2 UU Penyelesaian Perselisihan Hubungan Industrial mendefinisikan perselisihan hak sebagai perselisihan yang timbul karena tidak dipenuhinya hak, akibat adanya perbedaan pelaksanaan atau penafsiran terhadap ketentuan peraturan perundang-undangan, perjanjian kerja, peraturan perusahaan atau perjanjian kerja bersama. Dalam penjelasan Pasal 2 huruf a UU Penyelesaian Perselisihan Hubungan Industrial, perselisihan hak merupakan perselisihan mengenai hak normatif yang telah ditetapkan ketentuannya pada perjanjian kerja, peraturan perusahaan, perjanjian kerja bersama atau peraturan perundang-undangan.

\footnotetext{
${ }^{16}$ Iman Soepomo, Op.Cit.

${ }^{17}$ Lanny Ramli, Op.Cit.[47].
} 
Maka, dapat diketahui berdasarkan jenis perselisihan hubungan industrial antara perselisihan hak dengan perselisihan kepentingan terdapat perbedaan, yaitu objek dalam perselisihan hak adalah tidak terpenuhinya hak yang telah ditentukan pada perjanjian kerja, peraturan perusahaan, perjanjian kerja bersama atau peraturan perundang-undangan. Sedangkan objek dalam perselisihan kepentingan adalah adanya ketidak sepemahaman atau tidak sependapat mengenai perubahan atau perbaikan syarat-syarat kerja dalam perjanjian kerja, peraturan perusahaan atau perjanjian kerja bersama. Jika dikaitkan dalam bahasan penelitian ini, objek yang dipermasalahkan merupakan tidak terpenuhinya hak menyusui bagi pekerja perempuan menyusui, maka perselisihan yang dimaksud adalah perselisihan hak.

\section{Upaya Hukum Bagi Pekerja Perempuan Menyusui Yang Tidak Dipenuhi Haknya}

Terkait dengan pekerja perempuan yang tidak dipenuhi haknya yaitu hak menyusui di tempat kerja, jika hak tersebut tidak dicantumkan dalam perjanjian kerja bersama dan terjadi sengketa, maka termasuk dalam perselisihan hak. Hal ini sesuai dengan ketentuan Pasal 1 ayat (2) UU Penyelesaian Perselisihan Hubungan Industrial mengenai perselisihan hak yaitu "perselisihan yang timbul karena tidak dipenuhinya hak, akibat adanya perbedaan pelaksanaan atau penafsiran terhadap ketentuan peraturan perundang-undangan, perjanjian kerja, peraturan perusahaan, atau perjanjian bersama”. Namun, jika hak tersebut sudah dicantumkan dalam perjanjian kerja bersama dan terjadi sengketa, maka termasuk dalam perselisihan kepentingan karena objek yang dipermasalahkan adalah hak salah satu pihak dalam perjanjian kerja bersama yang tidak dipenuhi oleh pihak yang berkewajiban.

Sesuai penjelasan di atas, maka upaya hukum yang dapat dilakukan jika terjadi sengketa mengenai hak menyusui buruh perempuan yang pertama adalah melalui mekanisme perundingan bipartit. Jika tidak tercapai kata sepakat, maka dapat dilanjutkan melalui mekanisme non litigasi mediasi atau mekanisme litigasi yaitu Pengadilan Hubungan Industrial pada Pengadilan Negeri setempat. Jika para pihak memilih melalui mediasi dan tetap tidak tercapai kata sepakat, maka dapat dilanjutkan melalui ranah litigasi yaitu melalui Pengadilan Hubungan Industrial 
pada Pengadilan Negeri setempat. Namun jika sengketa yang dimaksud merupakan perselisihan hak, maka dapat melalui jalur non-litigasi lain yaitu melalui mekanisme arbitrase. Dalam hal telah dijatuhkan putusan Pengadilan Hubungan Industrial, masih dapat dilanjutkan ke tingkat kasasi pada Mahkamah Agung.

\section{Kesimpulan}

Perjanjian Kerja Bersama yang tidak mencantumkan ketentuan mengenai hak buruh atau pekerja perempuan untuk menyusui pada waktu kerja di tempat kerja tidak batal demi hukum. Landasan hukum bagi hak buruh atau pekerja wanita untuk menyusui pada waktu kerja di tempat kerja tercantum dalam Pasal 83 UU Ketenagakerjaan, Pasal 128 ayat (2) UU Kesehatan, Pasal 30 Peraturan Pemerintah Nomor 33 Tahun 2012 tentang Pemberian Air Susu Ibu Eksklusif, dan Pasal 3 Peraturan Menteri Kesehatan Nomor 15 Tahun 2013 tentang Tata Cara Penyediaan Fasilitas Khusus Menyusui dan/atau Memerah Air Susu Ibu. Selain itu, Pasal 200 jo. 201 Undang-Undang Nomor 36 Tahun 2009 tentang Kesehatan, juga memberikan sanksi pidana bagi semua pihak yang menghalangi pemenuhan hak tersebut, tidak terkecuali pengusaha.

Jika terjadi sengketa mengenai pemenuhan hak buruh atau pekerja perempuan untuk menyusui, maka termasuk dalam jenis perselisihan hubungan industrial yaitu perselisihan hak. Upaya hukum yang dapat dilakukan oleh buruh atau pekerja dalam sengketa dapat melalui jalur non-litigasi yaitu menggunakan mekanisme perundingan bipartit dan mediasi. Jika sengketa telah melalui melalui jalur nonlitigasi yaitu mekanisme perundingan bipartit dan mediasi namun tidak menemui kesepakatan, maka dapat dimajukan ke jalur litigasi melalui Pengadilan Hubungan Industrial pada Pengadilan Negeri dimana sengketa tersebut terjadi.

\section{Daftar Bacaan}

\section{Buku}

F.X. Djamila Dji dan Wiwoho Soedjono: Perjanjian Perburuhan dan Hubungan Perburuhan Pancasila (Bina Aksara 1990). 
Iman Soepomo: Pengantar Hukum Perburuhan" (Djambatan 1990).

Lanny Ramli: Hukum Ketenagakerjaan (Airlangga University Press 2008).

WHO: Infant and Young Child Feeding, Model Chapter for Textbooks for Medical Students and Allied Health Professionals (World Health Organization 2009).

\section{Jurnal}

Catarina Cori Pradnya Paramita, Andi Wijayanto 'Pengaruh Keselamatan dan Kesehatan Kerja terhadap Prestasi Kerja Karyawan pada PT. PLN (PERSERO) APJ Semarang, (2012) 1 Jurnal Administrasi Bisnis.

Cesar G Victora dkk,' Breastfeeding in the 21 st Century: Epidemiology, Mechanisms, and Lifelong Effect,' (2016) 387 The Lancet Journal.

Elza Qorina Pangestika 'Pengaturan Hak Menyusui Anak Pada Waktu Kerja Dalam Hukum Ketenagakerjaan', (2018) 1 Wacana Hukum.

Ni Wayan Mega Jayantri' Perlindungan Hukum Terhadap Pekerja Perempuan Pada Malam Hari di Minimarket Alfamart Mataram (Studi Berdasarkan UndangUndang Nomor 13 Tahun 2003 tentang Ketenagakerjaan', (2013) Jurnal Ilmiah Fakultas Hukum Universitas Mataram.

\section{Laman}

Badan Pusat Statistik: Keadaan Angkatan Kerja di Indonesia Februari 2019. $<$ https://www.bps.go.id/publication/2019/05/31/a96ce41f72e59d5dfb1cad9f/ keadaan-angkatan-kerja-di-indonesia-februari-2019.html>, diakses pada tanggal 29 Juli 2020.

\section{Perundang-undangan}

Undang-Undang Dasar Negara Republik Indonesia Tahun 1945.

Kitab Undang-Undang Hukum Perdata (Burgerlijk Wetboek, Staatsblad 1847 Nomor 23).

Kitab Undang-Undang Hukum Pidana.

Undang-Undang Nomor 1 Tahun 1974 tentang Perkawinan (Lembaran Negara Republik Indonesia Tahun 1974 Nomor 1, Tambahan Lembaran Negara Nomor 3019).

Undang-Undang Nomor 4 Tahun 1979 tentang Kesejahteraan Anak (Lembaran 
Negara Republik Indonesia Tahun 1979 Nomor 32, Tambahan Lembaran Negara Republik Indonesia Tahun Nomor 3143).

Undang-Undang Nomor 39 Tahun 1999 tentang Hak Asasi Manusia (Lembaran Negara Republik Indonesia Tahun 1999 Nomor 165, Tambahan Lembaran Negara Republik Indonesia Nomor 3886).

Undang-Undang Nomor 13 Tahun 2003 tentang Ketenagakerjaan (Lembaran Negara Republik Indonesia Tahun 2003 Nomor 39, Tambahan Lembaran Negara Republik Indonesia Nomor 4279).

Undang-Undang Nomor 2 Tahun 2004 tentang Penyelesaian Perselisihan Hubungan Industrial (Lembaran Negara Republik Indonesia Tahun 2004 Nomor 6, Tambahan Lembaran Negara Republik Indonesia Nomor 4356).

Undang-Undang Nomor 36 Tahun 2009 tentang Kesehatan (Lembaran Negara Republik Indonesia Tahun 2009 Nomor 144, Tambahan Lembaran Negara Republik Indonesia Nomor 5063).

Undang-Undang Nomor 35 Tahun 2014 tentang Perubahan Atas Undang-Undang Nomor 23 Tahun 2002 tentang Perlindungan Anak (Lembaran Negara Republik Indonesia Tahun 2014 Nomor 297, Tambahan Lembaran Negara Republik Indonesia Nomor 5606).

Peraturan Pemerintah Nomor 33 Tahun 2012 tentang Pemberian Air Susu Ibu Eksklusif (Lembaran Negara Republik Indonesia Tahun 2012 Nomor 58, Tambahan Lembaran Negara Republik Indonesia Nomor 5291).

Peraturan Menteri Kesehatan Republik Indonesia Nomor 15 Tahun 2013 tentang Tata Cara Penyediaan Fasilitas Khusus Menyusui Dan/Atau Memerah Air Susu Ibu (Berita Negara Republik Indonesia Tahun 2013 Nomor 441). 
Timothy Ronald: Kewajiban Pengusaha Menyediakan

--halaman ini sengaja dibiarkan kosong-- 